УДК 37.091.321:37013.83

DOI:

Володимир Піддячий, доктор філософії, старший науковий співробітник відділу андрагогіки Інституту педагогічної освіти і освіти дорослих імені Івана Зязюна НАПН України

\title{
СУТНІСТЬ І ЗМІСТ АНДРАГОГІЧНОЇ КОМПЕТЕНТНОСТІ ПЕДАГОГІВ
}

Досліджено сутність і зміст андрагогічної компетентності педагогів. 3'ясовано, щзо модернізація системи освіти України зумовлена різновекторними потребами суспільства та держави і відбувається з урахуванням досягнень науки і техніки, глобалізаційних та інтеграційних процесів світового, національного й регіонального рівнів. Вказано на важливості перегляду вимог до фахової підготовки педагогів, які забезпечують навчання, виховання і розвитоклюдини на різних вікових етапах. Акцентовано увагу на потребах суспільства у підготовці моральних та сочіально-професійно розвинених фахівців здатних ефективно працювати і вирішувати труднощті різного рівня складності. Наголошено, щзо актуальність розвитку андрагогічної компетентності педагогів зумовлена бажанням дорослих суб 'єктів учіння підвищувати рівень власних знань, умінь, навичок та інших якостей для розв 'язання практичних завдань, готовність до трудовоі діяльності, сімейного життя та інших видів активності.

Ключові слова: андрагогічна компетентність педагога; групова динаміка дорослої аудиторії; інтерактивні методи навчання; менторство; модерація; фасилітація.

תim. 13.

Volodymyr Piddiachyi, Doctor of Science (Philosophy), Senior Researcher of the Andragogic Department,

Ivan Ziaziun Institute of Pedagogical Education and Adult Education of the NAPS of Ukraine

\section{THE ESSENCE AND CONTENT OF TEACHERS'ANDRAGOGICAL COMPETENCE}

The essence and content of teachers' andragogical competence are considered. It was found that the modernization of the education system in Ukraine is caused by the diverse needs of society and the state and it involves the achievements of science and technology, globalization and integration processes at the global, national and regional levels. The importance of revising the requirements for the professional training of teachers who provide training, education and human development at different ages is pointed out. Emphasis is placed on the needs of society in the training of moral and socio-professionally developed professionals who are able to work effectively and solve problems of varying complexity. It is highlighted that the relevance of enhancing teachers' andragogical competence is due to the desire of adult learners to improve their knowledge, skills, abilities and other qualities in order to solve practical problems. According to the results of the analysis of domestic and foreign normative-legal documents and achievements of scientists, the author allocates the indicators which are applied to define individual's adulthood. It is noted that biological age is one of the main indicators to determine a person's adulthood; however, moral maturity, psychological and social readiness for work, family life and other activities are distinguished among others. Emphasis is placed on the need to take into account the peculiarities of adult learning in the educational process. The significance of diagnosing the educational needs and requests of adults in order to increase the effectiveness of their education, upbringing and development is pointed out. The importance of the teacher's mastery of methods of moderation, facilitation and mentoring to build effective individual and group interaction with the subjects of learning is underscored. The peculiarities of the activity, functions, tasks and responsibilities of the mentor are highlighted. The stages of facilitation and the principles of the facilitator's work are described. Interactive teaching methods are considered; their efficiency for teaching adults is indicated. The importance of reflection on educational activities is covered.

Keywords: andragogic competence; group dynamics of adult audience; mentoring; moderation; educational needs and requests; interactive teaching methods; teacher; reflection; facilitation.

П остановка проблеми. Розвиток науки і техніки глобалізаційні та інтеграційні процеси на світовому національному й регіональному рівнях зумовили соціально-економічні трансформації суспільства та держави. Особливо відчутно це вплинуло на систему освіти, що, незважаючи на свою об'єктивну й виважену консервативність, змушена постійно змінюватись і модернізуватись з урахуванням різновекторних потреб особистості, суспільства та держави $[6,3]$. У зв'язку з цим досить часто переглядаються вимоги до фахової підготовки педагогів, оскільки вони: 1) безпосередньо забезпечують навчання, виховання і розвиток суб'єктів учіння на різних вікових етапах онтогенезу; 2) формують життєво і професійно важливі якості особистості (відповідальність, здатність до самоосвіти, самовиховання та 
саморозвитку). Науковці наголошують, що у сучасних умовах $є$ гострий запит на особистість 3 високим рівнем моральності та соціальнопрофесійного розвитку, здатну ефективно працювати і долати труднощі різної складності [7, 98-108]. Підготовка педагогів до роботи 3 дорослими суб'єктами учіння зумовлена визнанням важливості концепції освіти впродовж життя та бажанням підвищувати рівень власної компетентності з метою розв'язання практичних завдань. Це вказує на необхідність розвитку у педагогів андрагогічної компетентності з метою підвищення ефективності взаємодії із дорослими суб'єктами учіння.

Аналіз останніх досліджень і публікацій. Дослідження поняття “дорослість” відображені у працях вітчизняних (А. Боярська-Хоменко, Л. Лук'янова Л. Сігаєва та ін.) і зарубіжних учених (Ч. Катански, С. Лерч, Х. Меулманн, 3. П'єтрасінський, К. Хамсі та ін.). Наукове обгрунтування андрагогічної компетентності педагогів представлене у напрацюваннях І. Зель, О. Михальчук, О. Огієнко та ін.. Аналіз освітніх методів модерації, фасилітації та менторства містять студії Т. Вільгельма, А. Едмліллера, В. Кириченко, Р. Овчарова, В. Радченко, К. Роджерса, Л. Селиванова та ін.

Мета статті - дослідити сутність і зміст андрагогічної компетентності педагогів.

Виклад основного матеріалу дослідження. Андрагогічну компетентність педагога розглядаємо як “готовність до роботи з дорослою аудиторією, що передбачає вміння визначати освітні потреби і запити, ураховувати особливості мотивації, навчання, групової динаміки дорослої аудиторії, застосовувати технології модерації, фасилітації, менторства, залучати аудиторію до інтерактивної взаємодії впродовж навчання, визначати результати навчання, спонукати аудиторію до рефлексії” [3].

Досліджуючи питання "Кого відносять до дорослих?”, проаналізовано вітчизняні та зарубіжні нормативно-правові документи й напрацювання науковців. 3'ясовано, що, згідно із національним законодавством Австрії, Польщі, Чехії та України, дорослою є людина, яка досягла 18 років. Натомість побутує інша точка зору у Федеративній Республіці Німеччині, за якою дорослою можна вважати людину, якій виконалося більше 21 року. 3 біологічної точки зору вони пов'язують дорослість із статевою зрілістю. У соціальному ракурсі, дорослою у німецькому суспільстві вважають людину, що здобула знання, уміння та навички, достатні для автономного та відповідального прийняття рішень, пов'язаних із забезпеченням життя і праці [12].
На основі аналізу досліджень учених виокремлено підходи до вікового розгляду дорослості. Зокрема, М. Петеркова виокремлює три стадії дорослості: молода (до 30 років), середня (до 45 років) та старша (до 60 років) [13]. На думку Ю. Кулюткина, дорослою є людина, яка досягла 16 років В. Слободчиков та Г. Цукерман вважають, що цей період настає після 17 років, О. Степанова - 18 років. На думку Б. Ананьева, дорослою можна називати людину, яка досягла 21 рік [1, 29-43)]. Водночас, точні i загальноприйняті вікові межі, що визначають настання дорослості, назвати складно, оскільки цей період життя людини характеризується не тільки біологічним віком, але і психологічною та соціальною зрілістю, громадянською і трудовою активністю, рівнем мислення й поведінки, цілями, цінностями та життєвим досвідом.

В освітньому процесі доцільно враховувати, що навчання дорослої людини має свої особливості. До них відносять: 1) спирання на життєвий досвід суб'єктів учіння впродовж навчання; 2) скептичне ставлення до змісту, форм та методів навчання; 3) бажання самореалізуватися і проявляти самостійність у навчанні; 4) вплив побутових, соціальних та часових умов на результативність навчання; 5) можливість обирати освітню програму; 6) застосовувати здобуті компетентності на практиці; 7) реалізацію особистісного потенціалу та досягнення поставлених цілей $[6$, 191].

Організовуючи навчання дорослих, важливо визначити їхні освітні потреби і запити. Це сприятиме більш ефективній організації навчання, виховання та розвитку, які мають динамічний характер і відбуваються у межа певної соціальної групи. 3 метою дослідження освітніх потреб і запитів дорослих використовуються такі методи:

1) кабінетне дослідження. Воно передбачає збір, аналіз, узагальнення та систематизацію необхідної інформації про досліджуваний об'єкт 3 різних джерел (законодавчих документів; статистичних досліджень; публікацій у ЗМІ та Інтернеті; баз даних; результатів досліджень науково-дослідних установ та міжнародних організацій; матеріалів наукових конференцій, семінарів; довідкових джерел тощо);

2) фокус-групи. Використання цього методу спрямоване на отримання оцінної та емоційно вираженої інформацію про досліджуваний предмет. Він передбачає неформальне обговорення певної проблемної теми під керівництвом модератора з можливістю відео- та аудіозапису. Зазвичай воно триває впродовж 1 год. 30 хв. і регламентом передбачається участь від 


\section{СУТНІСТЬ І ЗМІСТ АНДРАГОГІЧНОЇ КОМПЕТЕНТНОСТІ ПЕДАГОГІВ}

8 до 10 осіб. Серед переваг методу можна виокремити можливість отримання інформації, яку складно виявити за допомогою тестів. До недоліків відносять складність організації та проведення дискусії, а також аналізу отриманої інформації;

3) глибинне інтерв'ю. Воно передбачає неформальне індивідуальне спілкування 3 опитуваним на наперед визначені і сплановані теми. Зазвичай його використовують для дослідження чутливих тем, а також у випадках складності проведення групових дискусій. Серед особливостей цього методу можна виокремити нестандартизованість та звернення уваги на невербальні ознаки спілкування (жести, міміка, пози, інтонація тощо). Глибинне інтерв'ю використовується 3 метою з'ясування деталей досліджуваної проблеми;

4) анкетування. Воно передбачає надання письмових відповідей на спеціально сформульовані питання, які відповідають меті дослідження. Використання цього методу зумовлене необхідністю отримання фактичних, точних, однозначних, конкретних даних та 3'ясуванням ставлення до певної проблеми. Серед переваг анкетування можна виокремити порівняно низькі затрати часу та ресурсів, отримання об'єктивних результатів за допомогою методів математичної статистики. До недоліків відносять складність контролю достовірності відповідей;

5) особисті інтерв'ю. Особливість цього методу полягає у тому, що інтерв'юер упродовж безпосереднього спілкування із респондентом зачитує наперед сформульовані, попередньо сплановані питання і варіанти відповідей на них, потім фіксує їх в опитувальнику. Воно може проводитись як на роботі, так і за місцем навчання або проживання тощо.

Упродовж навчання дорослих суб' єктів учіння важливою $є$ взаємодія із більш досвідченим фахівцем, який ділиться необхідними знаннями, дає виважені рекомендації і наставляє. У зв'язку із цим одним із ефективних методів навчання дорослих $\epsilon$ менторство. Його застосування передбачає створення умов для набуття досвіду професійної діяльності, а також виявлення особистісних якостей, здібностей, схильностей та інтересів під керівництвом досвідченого фахівця. Це передбачає опікування задля розкриття особистісно-професійного потенціалу через узгоджені види діяльності. Менторство $є$ напруженою роботою, яка характеризується вторинністю матеріальної винагороди [10, 139]. Окрім того ментор зазвичай працює із суб'єктами учіння у вільний від роботи час і не обмежується рамками консультацій, навчальних занять чи заходів.

До основних методів роботи ментора відносять: опис, бесіду, демонстрування та аналіз життєвого досвіду. Вони характеризуються наявністю мотиваційної частини, що пояснює необхідні умови для досягнення успіху. Менторство застосовують з метою: 1) професійного та особистісного розвитку педагогів; 2) поліпшення адаптації співробітників до нових умов, викликаних динамічними змінами суспільства, освіти, науки, техніки тощо; 3) збереження працюючого персоналу на засадах підвищення задоволеності роботою тощо. У сфері освіти ментор є досвідченим педагогом, який наставляє молодих колег, що проходять адаптацію у закладі освіти. Він на рівні неформальної комунікації передає цінності, досвід, знання, норми професійного етикету, сприяє вихованню, професійній підготовці та зростанню, надає поради, допомогу, підказки, психологічну підтримку в роботі, професійному розвитку тощо. Ментор сприяє не тільки професійному розвитку фахівця, але й позитивно впливає на його особистість. Це, зі свого боку підвищує результативність роботи.

Ментор виконує такі функції: 1) передає необхідні знання уміння навички і цінності; 2) показує, як застосовувати отримані знання на практиці; 3 ) конструктивно критикує; 4) розвиває професійну культуру; 5) ознайомлює із необхідною документацією (інструкціями, правилами тощо); 6) допомагає врегулювати проблемні ситуації, аналізувати роботу; 7) сприяє налагодженню професійної комунікації.

Одним із його завдань $є$ роз'яснення важливості набуття власного досвіду, спираючись на цікавий та успішний досвід інших людей. Діяльність ментора є різнобічною: 1) визначення пріоритетів; 2) допомога у розробленні ефективної стратегіï; 3) забезпечення зворотного зв'язку; 4) коригування діяльності; 5) моральна та емоційна підтримка при виникненні труднощів; 6) оцінка ідей та надання пропозицій; 7) пошук партнерів; 8) слідкування за прогресом виконання завдань; 9) структурування змісту проекту; $10)$ формування мети, завдань і алгоритму діяльності тощо.

Серед особистісних якостей ментора виокремлюють високу самоорганізацію, відповідальність, комунікативність, тактовність, терплячість, цілеспрямованість, чуйність та естетичність. Це сприяє підвищенню мотивації та ефективності навчання. 


\section{СУТНІСТЬ І ЗМІСТ АНДРАГОГІЧНОӤ КОМПЕТЕНТНОСТІ ПЕДАГОГІВ}

До переваг методу менторства можна віднести:

1) навчання впродовж професійної діяльності на робочому місці;

2) індивідуальний підхід до організації суб'єктсуб'єктної взаємодії;

3) підвищення швидкості професійної адаптації;

4) формування позитивної мотивації до роботи;

5) стабілізація та розвиток кадрового ресурсу установи.

Серед його недоліків виокремлюють:

1) відволікання ментора від виконання посадових обов'язків;

2) несистемний характер взаємодії [9, 116-119].

Метод менторства передбачає такі основні елементи: 1) прийняття ментором зобов'язання допомагати в особистісно-професійному розвитку впродовж усього періоду взаємодії; 2) створення умов для здобуття підопічним компетентностей, потрібних для виконання наперед визначених робочих завдань; 3) розширення кругозору, зміна ставлення до роботи та навколишніх, формування цінностей; 4) демонстрування на власному прикладі знань, умінь, навичок, цінностей, якостей та технологій виконання певної діяльності; 5 ) отримання зворотного зв'язку щодо результатів навчання, їх практичного застосування та зроблених висновків.

Навчання дорослих може мати як індивідуальний, так і груповий характер. Ефективними методами організації та управління груповою динамікою дорослої аудиторії впродовж навчання є модерація та фасилітація. Освітній метод модерації був розроблений у Німеччині у 60-70-х pр.. На початку свого виникнення його розглядали як метод маніпуляції, що спрямований на підведення учасників до прийняття очевидного рішення, яке було заздалегідь сплановане. Відтоді і до сьогодення він пройшов апробацію у різних країнах і зазнав значних змін. Сформувалось уявлення, що модерація - це метод інтерактивної взаємодії, спрямований на колективне знаходження спільного рішення певної проблеми, досягнення поставлених завдань 3 оптимальним використання робочого часу і можливостей кожного без використання маніпуляцій. Він застосовується під час: командної роботи у проєктній групі, круглого столу чи інших форматів зустрічей. Разом з цим, модерація передбачає логічне, структуроване проведення начальних занять і професійних нарад 3 метою виявлення проблеми та пошуку шляхів її вирішення на основі спільного прийнятого рішення. Модератор здійснює організацію групової роботи, активізує взаємодію її учасників на основі демократичних принципів, фіксує результати проведеної дискусії, забезпечує конструктивний діалог. Він має володіти предметною областю, у якій ведеться обговорення, адже його завданнями є: 1) концентрація уваги на сутності теми, що обговорюється, та передати частину власних професійних знань; 2) виявлення та врегулювання непорозуміння між учасниками, що гальмують роботу групи; 3) усунення чинників, що знижують мотивацію учасників. До обов'язків модератора належать: підготовка, проведення, оцінка і підбиття підсумків робочого засідання. Він $є$ посередником, що допомагає команді визначити та досягти спільну мету. Модератор має володіти такими якостями: чесність, відкритість, самовладання, оптимізм, дієвість та толерантність, що викликають довіру з боку колективу. Одна із функцій модератора підтримка учасників та слідкування за дотриманням етичних принципів групової роботи.

Серед технік модерації виокремлюють кластер, ментальні карти, мозковий штурм, рольові ігри тощо [2]. Напередодні проведення модерації: 1) учасників повідомляють про привід, мету, підстави, бажані результати та корисність роботи; 2) надають доступ до основної інформації; 3) створюють атмосферу рівності і свободи у висловлюваннях упродовж колективної роботи; 4) надають перевагу обгрунтованим аргументам, а не статусу учасників. Організовуючи дискусію, модератор здійснює і контролює підготовку учасників до модерації, розподіляє їх по малих групах, передає роздатковий матеріал, збирає матеріали доповідей та презентацій тощо). Розпочинається модерація оголошенням теми і програми. Розглянувши окремий пункт плану, даються завдання і організовується дискусія. Модератор контролює дотримання регламенту та норм поведінки учасників. На завершальному етапі дискусії здійснюються рефлексія та підбиваються підсумки, а також надається загальна оцінка виконаної роботи.

Модерація допомагає зібрати команду, спрямувати енергію її учасників у потрібне русло, систематизувати ідеї, що виникли впродовж спільної роботи. Використання цього методу сприяє підвищенню мотивації пізнавальної активності учасників групи, розвиває їх уяву, мислення, пошукові та комунікативні здібності, готовність працювати у команді, уміння проводити перемовини і дискусії, брати відповідальність за прийняті рішення, сприяє кращому розумінню процесів, що відбуваються знаходженню ефективних варіантів подолання проблем.

До позитивних ознак методу модерації можна віднести: 
1) концентрацію на головному; 2) прозорість результатів; 3) підвищення рівня корпоративної культури та мотивації діяльності [11]. Вдало організована модерація поліпшує культуру спілкування, дискусії та взаємодії у команді.

Ефективним методом управління груповою динамікою дорослої аудиторії є фасилітація. Це поняття було введене Г. Триплет, Ф. Олпорт та В. Меде. Перша праця, присвячена соціальній фасилітації як напряму соціально-психологічних досліджень, була опублікована у 1965 p. Соціально-психологічна фасилітація спрямована на полегшення, оптимізацію і підвищення продуктивності міжособистісної і групової взаємодії на засадах надання допомоги у розв'язанні поставлених завдань та цілей, досягненню спільної згоди щодо певних питань. Вона підвищує продуктивність групової роботи, мотивацію учасників, розкриває їх потенціал, сприяє конструктивному обговоренню суперечностей та проблем. Педагогічна фасилітація $є$ способом навчання на засадах надання допомоги самостійно знаходити відповіді на питання або допомогу у опануванні певних компетентностей. Вона використовується для стимулювання, заохочення, підвищення ініціативності. За К. Роджерсом, сенсом фасилітованого навчання є створення атмосфери, свободи, творчості, толерантності, відповідальності, акцентування на суб'єкт-суб'єктних стосунках. Водночас цим серед характеристик фасилітації навчання та виховання можна виокремити: 1) співпрацю на засадах розуміння та підтримки один одного;

2) конструктивне усунення навчальних та міжособистісних конфліктів;

3) уникнення конфронтації; 4) право на власну думку; 5) відсутність нав'язування власних думок іншим; 6) інтерес та повага до думок інших;

7) щирість та відкрите вираження своїх почуттів і переживань. Серед завдань, які можна розв'язати за допомогою фасилітації, можна виокремити: 1) аналіз наявної ситуації та виокремлення проблем; 2) напрацювання рішень; 3) вибір найефективніших варіантів рішення.

У своїх дослідженнях цього методу К. Роджерс зазначав, що фасилітатору мають бути притаманними такі якості, як щирість, довірливість, повага до думок співрозмовника, адже вони сприяють налагодженню продуктивних міжособистісних стосунків. Педагог, що виступає фасилітатором, своїм ставленням до суб'єктів учіння та діями стимулює їх розвиток, ініціативність та самостійність, сприяє налагодженню позитивних міжособистісних стосунків [4, 7-10].
Зазвичай фасилітація відбувається у три етапи:

1) вступний: а) постановка цілі; б) ознайомлення 3 регламентом;

в) визначення завдань та надання інструкцій щодо їх виконання;

2) організаційний: а) управління швидкістю роботи; б) слідкування за дотриманням регламенту та рухом до цілі; в) мотивація і стимулювання учасників, щоб усі були задіяні;

3) завершальний: а) підбиття підсумків, які б відповідали завданням; б) подяка учасникам за роботу; в) формулювання практичних рекомендацій для застосування у практичній діяльності.

Педагог-фасилітатор сприяє підвищенню виявлення ініціативності та самостійності суб'єктів учіння, сприяє формуванню міжособистісних стосунків. Серед основних принципів його роботи можна виокремити:

1) дотримання нейтральності щоб зберегти довіру до себе; 2) навчання комфортно себе почувати у емоційно насичених ситуаціях; 3) повага до напрацювань групи, навіть, якщо вони у деяких частинах помилкові; 4) дотримання цілей роботи групи.

Одним із головних завдань фасилітатора $є$ допомога кожному учаснику виявити свій потенціал. У зв'язку з цим він виконує такі функції: 1) залучає до участі; 2) сприяє взаєморозумінню; 3) стимулює напрацювання взаємоприйнятих рішень; 4) формує почуття спільної відповідальності.

Зважаючи на те, що інтерактивні методи вважаються найбільш ефективними для навчання дорослих, зазначимо, що умовно вони поділяються на:

1) початкові. Спрямовані на створення атмосфери доброзичливості взаємодовіри (вправи “криголами”: “оголошення”, “серветки”, “креативне привітання” тощо);

2) базові. Забезпечують розв'язання виокремлених проблем (зокрема, інтерактивні лекції, карусель, “кейс стаді”, мозковий штурм, обговорення, рольові ігри тощо);

3) прикінцеві. Передбачають підбиття підсумків (сенкан, вернісаж);

4) додаткові. Сприяють зниженню напруги, зміні виду діяльності, переходу з одного етапу до іншого.

Для визначення результатів навчання дорослих використовують методи: 1) контролю за ефективністю навчально-пізнавальної діяльності (графічний контроль; колоквіум; письмовий контроль; практична перевірка; програмований контроль; тестовий контроль; усне опитування); 
2) підсумкового контролю (залік, іспит); 3) методи самоконтролю (самоаналіз; самооцінювання, самоспостереження) [5, 118-123].

Важливим елементом навчання дорослих $€$ спонукання до рефлексії, яку розглядаємо як звернення свідомості на себе 3 метою самопізнання особистісних емоційних станів, дій тощо. Вона передбачає аналіз, виокремлення головного, оцінку проведеної роботи та поведінки 3 метою подальшого коригування та усунення недоліків, набуття рішучості та впевненості, реалізації потенційних можливостей. Застосування рефлексії дає можливість зрозуміти: 1) особистісні переживання та почуття; 2) недоліки і слабкі сторони; 3) рівень залежності від думок інших; 4) як подолати труднощі; 5) причини зроблених помилок; 6) можливості удосконалення роботи тощо.

Висновки і перспективи подальших досліджень.

1. Ефективність роботи педагога, що спрямована на навчання та виховання дорослих суб'єктів учіння, підвищиться на засадах розвитку андрагогічної компетентності, яка передбачає: застосування методів модерації, фасилітації та менторства; надання переваги використання інтерактивних методів навчання; врахування психологічних особливостей дорослих, їхніх потреб та запитів тощо.

2. В Україні, як і в багатьох інших країнах, дорослість людини пов'язують із досягненням повноліття, однак тлумачення поняття “дорослий суб'єкт учіння” не обмежується лише віком. Показниками, на основі яких визначається дорослість, є біологічний вік, моральна зрілість, психологічна та соціальна готовність до трудової діяльності, сімейного життя, інших видів активності.

3. Визначення освітніх потреб і запитів дорослих суб' єктів учіння сприятиме підвищенню ефективності їхнього навчання виховання та розвитку, оскільки становитиме для них цінність, відповідатиме їхнім запитам.

До перспективних напрямів подальших досліджень відносимо розроблення рекомендацій для викладачів закладів вищої освіти щодо розвитку андрагогічної компетентності.

\section{ЛІТЕРАТУРА}

1. Боярська-Хоменко, А.В. Визначення поняття “дорослість" у країнах Центральної та Східної Свропи. Теорія та методика навчання та виховання, 2018. № 44. С. 29-43.

2. Кириченко, В. Модерація як метод формування правової культури студентської молоді. Дидаскал, 2017. № 17. С. 267-271. URL: http://dspace.pnpu.edu.ua/bitstream/123456789/8791/ 1/Kirichenko.pdf (дата звернення 24.10.2021).

3. Наказ МОН "Про затвердження Орієнтовної навчальної програми підготовки тренерів для навчання педагогічних працівників, які навчатимуть учнів перших класів у 2018/2019 і 2019/2020 навчальних роках” (від 05.02.2018 № 97). URL: zakon.rada.gov.ua/rada/show/v009772918\#Техt (дата звернення 24.10.2021).

4. Овчарова, Р. В. Психолого-педагогическая фасилитация профессиональной деятельности учителя. Курган : Изд-во Курганского гос. ун-та, $2016.210 \mathrm{c}$.

5. Піддячий, В. М. Аналіз методів культурологічної підготовки майбутнього педагога. Молодь і ринок, 2016. № 9. C. 118-123. URL: http://nbuv.gov.ua/ UJRN/Mir_2016_9_27 (дата звернення 24.10.2021).

6. Піддячий, В. М. Сутність і зміст професіоналізації педагогів у контексті освіти впродовж життя. Вісник післядипломної освіти : зб. наук. пр. Київ: Юстон, 2020. Вип.13(42). C. 191. URL: https://lib.iitta.gov.ua/722527/ (дата звернення 24.10.2021).

7. Піддячий, М. І. Соціально-професійний розвиток старшокласників: праця як основа життедіяльності та поступу. Технологї інтеграиї змісту освіти : зб. наук. працьь. Інститут педагогіки НАПН України; Полтав. обл. ін-т післядиплом. пед. освіти ім. М. В. Остроградського, 2018. Вип. 10. С. 98-108. URL: https://lib.iitta.gov.ua/ 711857/ (дата звернення 24.10.2021).

8. Піддячий, М. I. Теоретико-методичні засади підготовки старшокласників до професійної діяльності в умовах профільного навчання: автореф. дис. д-ра пед. наук. Ін-т педагогіки НАПН України. Київ, 2010. 42 с.

9. Радченко, В. В. Менторство в системі післядипломної освіти лікаря. Медична освіта, 2019. №1. C. 116-120. URL: https://ojs.tdmu.edu.ua/ index.php/med_osvita/article/view/10094 (дата звернення 24.10.2021).

10. Селиванова, Л.И. Менторство саморазвития личности и профессионального становления студентов. Вісник Чернігівського національного педагогічного університету. Серія : Педагогічні науки, 2018. Вип. 151(1), С. 137-140. URL: http:// $\mathrm{n} \mathrm{b} \mathrm{u} \mathrm{v.} \mathrm{g} \mathrm{o} \mathrm{v.} \mathrm{u} \mathrm{a} \mathrm{/} \mathrm{U} \mathrm{J} \mathrm{R} \mathrm{N} \mathrm{/} \mathrm{V} \mathrm{c} \mathrm{h} \mathrm{d} \mathrm{p} \mathrm{u} \mathrm{P}$ 2018 151\%281\%29_32 (дата звернення 24.10.2021).

11. Edmliller A., Wilhelm T. Moderation. Freiburg: Haufe, 2012.

12.Hamcy, K. Erwachsener, H. Wörterbuch Erwachsenenpädagogik. Heilbrunn, 2001. 
13.Pietrasiński, Z. Rozwöj człowieka dorosłego. Warszawa: Wiedza Powszechna, 1990.

\section{REFERENCES}

1. Boiarska-Khomenko, A.V. (2018). Vyznachennia poniattia "doroslist" $\mathrm{u}$ krainakh tsentralnoi ta skhidnoi yevropy [Definition of "adulthood" in Central and Eastern Europe]. Theory and methods of teaching and education, no. 44, pp. 29-43. [in Ukrainian].

2. Kyrychenko, V. (2017). Moderatsiia yak metod formuvannia pravovoi kultury studentskoi molodi [Moderation as a method of forming the legal culture of student youth]. Dydaskal, no. 17, pp. 267-271. Available at: http://dspace.pnpu.edu.ua/bitstream/ 123456789/8791/1/Kirichenko.pdf(Accessed 24 Oct. 2021) [in Ukrainian].

3. Nakaz MON "Pro zatverdzhennia Oriientovnoi navchalnoi prohramy pidhotovky treneriv dlia navchannia pedahohichnykh pratsivnykiv, yaki navchatymut uchniv pershykh klasiv u 2018/2019 i 2019/2020 navchalnykh rokakh” (vid 05.02.2018 № 97) (2018). [Order of the Ministry of Education and Science "On approval of the Indicative curriculum for the training of trainers for teachers who will teach first-graders in 2018/2019 and 2019/2020 academic years” (from 05.02.2018 № 97)]. Available at: zakon.rada.gov.ua/rada/show/v0097729-18\#Text (Accessed 24 Oct. 2021) [in Ukrainian].

4. Ovcharova, R.V. (2016). Psykholohopedahohycheskaia fasylytatsyia professyonalnoi deiatelnosty uchytelia [Psychological and pedagogical facilitation of teacher's professional activity]. Kurhan, 210 p. [in Russian].

5. Piddiachyi, V.M. (2016). Analiz metodiv kulturolohichnoi pidhotovky maibutnoho pedahoha [Analysis of methods of cultural training of future teachers]. Youth \& market, no. 9, pp. 118-123. Available at: http://nbuv.gov.ua/UJRN/Mir 2016_9_27 (Accessed 24 Oct. 2021) [in Ukrainian].

6. Piddiachyi, V. M. (2020). Sutnist i zmist profesionalizatsii pedahohiv u konteksti osvity vprodovzh zhyttia [The essence and content of professionalization of teachers in the context of lifelong learning]. Bulletin of postgraduate education: a collection of scientific works, Vol.
13(42), pp. 191. Kyiv. Available at: https:// lib.iitta.gov.ua/722527/ (Accessed 24 Oct. 2021) [in Ukrainian].

7. Piddiachyi, M. I. (2018). Sotsialno-profesiinyi rozvytok starshoklasnykiv: pratsia yak osnova zhyttiediialnosti ta postupu [Socio-professional development of high school students: work as a basis for life and progress]. Technologies for integrating the content of education: a collection of scientific works, Vol. 10, pp. 98-108. Available at: https:// lib.iitta.gov.ua/711857/ (Accessed 24 Oct. 2021) [in Ukrainian].

8. Piddiachyi, M. I. (2010). Teoretykometodychni zasady pidhotovky starshoklasnykiv do profesiinoi diialnosti v umovakh profilnoho navchannia [Theoretical and methodical bases of preparation of senior pupils for professional activity in the conditions of profile training]. Extended abstract of Doctor's thesis. Institute of Pedagogy of the National Academy of Pedagogical Sciences of Ukraine. Kyiv [in Ukrainian].

9. Radchenko, V. V. (2019). Mentorstvo v systemi pisliadyplomnoi osvity likaria [Mentoring in the system of postgraduate education of a doctor]. Medical education, no.1, pp. 116-120. Available at: https:// ojs.tdmu.edu.ua/index.php/med osvita/article/view/ 10094 (Accessed 24 Oct. 2021) [in Ukrainian].

10.Selyvanova, L.Y. (2018). Mentorstvo samorazvytyia lychnosty y professyonalnoho stanovlenyia studentov [Mentoring of personality selfdevelopment and professional development of students]. Bulletin of Chernihiv National Pedagogical University. Series: Pedagogical sciences, Vol. 151(1), pp. 137-140. Available at: http:/ / $\mathrm{n} \mathrm{b}$ u v . g o v . u a / U J R N / VchdpuP_2018_151\%281\%29_32 (Accessed 24 Oct. 2021) [in Russian].

11. Edmliller, A., Wilhelm, T. (2012). Moderation. Freiburg: Haufe [in English].

12.Hamcy, K. Erwachsener, H. (2001) Wörterbuch Erwachsenenpädagogik [Dictionary of adult education]. Heilbrunn [in German].

13.Pietrasiński Z. (1990). Rozwöj człowieka dorostego [Adult's development]. Warszawa: Wiedza Powszechna [in Polish].

Стаття надійшла до редакції 11.10.2021

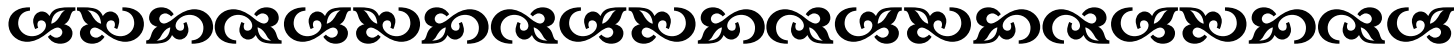

"Будь-яқе навчання людини - це не що інше, якмистецтво сприяти прагненню природи до свого розвитку". 